\title{
Impact Assessment of Developing Sustainable and Impact-Oriented Groundnut Seed System Under the Tropical Legumes (III) Project in Northern Nigeria
}

\author{
S. G. Mohammed, M. Halliru, J. M. Jibrin, I. Kapran, \\ and $H$. A. Ajeigbe
}

\section{Abstract}

Tropical Legumes III project as a development intervention focused on enhancing smallholder farmers' access to seeds of improved groundnut varieties using multi-stakeholder platforms. Open Data Kit was used to collect information from the platform members using structured questionnaires and focus group discussions (FGDs). Descriptive statistics and adoption score were used to analyze the data. Selection of appropriate project location, reliable beneficiaries, timely supply of seeds, and training on good agronomic practices (GAPs) and effective supervision on production were the major thrusts of the TL III project. The results indicated that the IP members accrued additional income ranging from $\$ 214$ to $\$ 453$ per hectare for wet season. The same increase in beneficiaries' income was reported per hectare for dry season from $\$ 193$ to $\$ 823$, respectively; all due to the TL III intervention. The results further indicated increasing access by farmers to services (e.g., improved seeds, extension, credit facilities, market, etc.) and enhanced productivity (farm size, pod and haulm yields). Findings further revealed an average increased market price of $21.5 \%$ and $18 \%$ for dry and

\footnotetext{
S. G. Mohammed $(\bowtie) \cdot$ J. M. Jibrin

Centre for Dryland Agriculture, Bayero University, Kano, Nigeria

e-mail: sanusi.gaya@buk.edu.ng

M. Halliru

Department of Agricultural Economics and Extension, Bayero University, Kano, Nigeria

I. Kapran

International Cr-ops Research Institute for the Semi-Arid Tropics (ICRISAT), Bamako, Mali

H. A. Ajeigbe

International Crops Research Institute for the Semi-Arid Tropics (ICRISAT), Kano, Nigeria
}

(C) The Author(s) 2021

E. Akpo et al. (eds.), Enhancing Smallholder Farmers'Access to Seed of

Improved Legume Varieties Through Multi-Stakeholder Platforms,

https://doi.org/10.1007/978-981-15-8014-7_6 
wet season groundnut production, respectively. There was high adoption score (78\%) of improved seeds and other GAPs. The study recommends the need to replicate similar interventions in other areas. Continued capacity building on GAPs and improved business management skills to Extension Agents and farmer groups will sustain the successes achieved by the TL III project.

\section{Keywords}

TL III project · Improved seed · Innovation platform · Groundnut productivity · Impacts $\cdot$ Nigeria

\subsection{Introduction}

Groundnut (Arachis hypogaea) is a major oilseed crop grown in the savanna zone of Nigeria. It is mainly grown for its nut, oil, and its haulms. Recently, the use of groundnut meal is becoming more recognized not only as a dietary supplement for children on protein poor cereals-based diets but also as effective treatment for protein related malnutrition in children. It is the 13th most important food crop of the world and the fourth most important source of edible oil. Its seeds contain high quality edible oil (50\%), easily digestible protein (25\%), and carbohydrates $(20 \%)$ (APS 2014).

Inconsistencies in government policies as regards production, transportation, and marketing of groundnut in Nigeria, which the government was actively involved before the disappearance of the groundnut pyramids of the North, have been identified as the major setback for the decline in groundnut production. The high rate of population growth in Nigeria calls for the need for more groundnut to meet the population need of the crop. Groundnut production in Nigeria is constrained by many factors notably biotic and abiotic factors. Principal among these factors are diseases especially rosette and leaf spots; drought; lack of quality planting materials; and inefficient market. Concerted efforts have been made by various initiatives such as the Tropical Legumes (TL) III project to alleviate these constraints to improve farmers' income and household food security as well as make Nigeria regain its lost glory in groundnut production.

The TL III project led by the International Crops Research Institute for the SemiArid Tropics (ICRISAT) is a major international initiative supported by Bill \& Melinda Gates Foundation (BMGF) and jointly implemented with International Center for Tropical Agriculture (CIAT), International Institute of Tropical Agriculture (IITA), and National Agricultural Research Systems (NARS) partners from sub-Saharan Africa and South East Asia. The project launched in 2015 has seven broad objectives and aims to develop improved cultivars of common bean, cowpea, chickpea, and groundnut and deliver their seed at scale to small holders in the BMGF focus geographies. 
In Nigeria the project focused on enhancing smallholder farmers' access to seed of improved varieties of groundnut and cowpeas through formation of multistakeholder innovation platforms (IPs) in selected states of the country. The project implementation is led by the Institute for Agricultural Research (IAR), Samaru while the Centre for Dryland Agriculture (CDA) of Bayero University, Kano specifically leads objective 6; the Seed Systems for Groundnut. The CDA worked with ADPs of six states-Bauchi, Jigawa, Kano, Kebbi, Zamfara, and Sokoto- to implement the project activities. The project ended in 2019 and seeks to assess the impact of the intervention to provide scientific documentation of the IP activities and achievements in the target states. The documentation considered the TL III intervention areas specifically the project beneficiaries. The Open Data Kit (ODK) was used to collect information from the platform members using structured questionnaires and Focus Group Discussions. Descriptive statistics and adoption score were used to analyze the data.

\subsection{Objectives of the Impact Study}

The study was undertaken to achieve the following objectives:

- To establish the significance of the innovation platforms and its effects in enhancing smallholder groundnut productivity

- To determine the additional income accruable to SHFs who benefited from the innovation platform activities

- To assess rate adoption of the improved groundnut varieties and associated technologies among SHFs

- Identify existing potential differences of productivity drivers (farm size, income, yield and access to market, etc.) before and after the project among SHFs

- Identify the major constraints militating against the innovation platform of the TL III project

\subsection{Establishment of the Innovation Platforms}

Seven IPs were established at the start of the project in 2015. However, for the purpose of this study only two of the IPs prominent in two Local Government Areas (LGA) of Bauchi (Ningi Groundnut Alkhairi Farmers' Association - NGAFA) and Kebbi (Bela Groundnut Cooperative Farmers - BGCF) States were considered. At the onset, the IPs started with 12 members each, which currently increased to 24 and 25 members for the NGAFA and the BGCF, respectively. Platform governance structure for each of the group involved steering committee at the beginning that facilitate membership election for smooth implementation of platform activities.

The composition of the two groups is made up of $32(65.3 \%)$ males and 17 $(34.7 \%)$ females, including 18 youths $(36.7 \%)$; those under the age of 35 years. One of the most important activity records for the groups was establishment of IPs, 
whose purpose was to create a forum for sharing knowledge on good agronomic practices and other services that will facilitate effectiveness especially members' groundnut productivity approaches. The strategy for establishing the IPs started by identification of appropriate location that can favor the production of groundnut seed for both wet and dry seasons. Emphasis was given to Fadama areas or those with potential sources of water particularly for the dry season groundnut seed production activities. The next aspect involved sensitization, identification, and registration of stakeholders with interest and concerns in groundnut seed production value chain. Selected farmers were provided initially with foundation seeds of four released varieties of groundnut and superphosphate fertilizer enough to commence production of 5 ha by each group. The varieties produced were Samnut 24 for all farmers in Bauchi State and Samnut 24, Samnut 25, and Samnut 26 for their counterparts in Kebbi State. The farmers were continuously monitored and trained by EAs who provided regular trainings in the application of GAPs for groundnut seed production.

\subsection{Composition, Roles, and Responsibilities of the IP Members}

The composition of the IP and other stakeholders such as seed companies, processors, agro-input dealers, community leaders, extension agents, and buyers/marketers from nearby communities within the study area is depicted in Table 6.1. The innovation platform serves as an umbrella where members meet on monthly basis to discuss matters associated with groundnut seed production in the presence of the EAs responsible for the communities. The major responsibility of the IP members was to produce quality seeds of improved groundnut varieties for supply to interested members of their communities and beyond. This turned out to be a significant effort to facilitate efficient development of the groundnut seed system and quality of groundnut grain production.

\subsection{Facilitation of Innovation Platform Activities}

The IP programs are facilitated by the EAs and the major activities undertaken include creation of awareness among community members, pre-season training on Good Agronomic Practices (GAPs) for groundnut seed production, and periodic supervision of members' activities during pre-production, production, and postproduction periods. Prior to the commencement of production activities, annual preseason trainings are provided to the members of the IPs. Areas of pre-season training covered GAPs ranging from site selection, land preparation, sowing, field sanitation, fertilizer application, and harvest and postharvest operations. The EAs in the project areas ensure maximum adherence to the GAPs among the selected farmers' fields. 
Table 6.1 Roles and responsibilities of various stakeholders

\begin{tabular}{|c|c|}
\hline $\begin{array}{l}\text { Categories of } \\
\text { members }\end{array}$ & Roles and responsibilities \\
\hline $\begin{array}{l}\text { Farmer seed } \\
\text { producers }\end{array}$ & $\begin{array}{l}\text { Seed multiplication at community levels is the sole responsibility of farmers. } \\
\text { Select few farmers were trained to produce foundation seeds. The partner } \\
\text { Agricultural Development Projects distributed the foundation seeds and } \\
\text { fertilizers to other seed growers who produced certified seeds following } \\
\text { recommended production and certification practices. The certified seeds } \\
\text { produced were further distributed to many farmers in different communities } \\
\text { to produce grain for consumption and other market needs. Production fields } \\
\text { were certified by the National Agricultural Seeds Council of Nigeria. Quality } \\
\text { seeds recovered from the producers were kept and distributed to other } \\
\text { farmers in same and neighboring communities for grain production }\end{array}$ \\
\hline Seed company & $\begin{array}{l}\text { Organized demonstration plots in communities to popularize new varieties. } \\
\text { Device out-growers scheme to produce foundation and certified seeds, which } \\
\text { they buy back. Sale of seeds in small seed packs to facilitate access to } \\
\text { improved groundnut varieties by farmers }\end{array}$ \\
\hline ADP staff & $\begin{array}{l}\text { Select and organize farmers into groups, provide extension services, training, } \\
\text { supervision, and coordination of all activities for effective delivery of the TL } \\
\text { III project }\end{array}$ \\
\hline $\begin{array}{l}\text { Community } \\
\text { leaders }\end{array}$ & $\begin{array}{l}\text { Important pillars of communities; provide leadership roles and ensure } \\
\text { cooperation of farmers in IPs and sustainability of interventions }\end{array}$ \\
\hline $\begin{array}{l}\text { Extension } \\
\text { agents }\end{array}$ & $\begin{array}{l}\text { Field agents that provide technical support at field level especially on GAPs } \\
\text { and other postharvest operations. The EAs also play important roles in } \\
\text { guidance, trainings, input sourcing, coordination of demonstration plots and } \\
\text { field days among others }\end{array}$ \\
\hline Traders & Responsible for input and output purchases. They are important pillars in IPs \\
\hline Processors & $\begin{array}{l}\text { These are important stakeholders in groundnut value chains. The role of the } \\
\text { processors is value addition to groundnut grains produced in communities }\end{array}$ \\
\hline Local media & $\begin{array}{l}\text { Solely responsible for the extension delivery to communities. All the state } \\
\text { ADPs have functional media units with designated weekly programs on radio } \\
\text { and TV with wide coverage that extend improved agricultural practices to } \\
\text { communities }\end{array}$ \\
\hline Research & $\begin{array}{l}\text { Develop varieties and associated production technologies. They facilitate } \\
\text { innovations that encourage groundnut producers to properly engage in seed } \\
\text { production }\end{array}$ \\
\hline
\end{tabular}

\subsection{Achievements of the Platform}

\subsubsection{Access to Knowledge and Farm Advisory Services}

Achievements in the areas of access to knowledge and farm advisory services are required to be documented in any development project. Findings from this study indicated significant increase $(98 \%)$ in extension advisory services of the IP members following the TL III project compared to the low advisory level (38\%) before the intervention. This increase was attributed to the TL III IP support in training and frequent supervision by EAs in the project areas. 


\subsubsection{Training on Improved Groundnut Seed Production}

The documentation further made enquiry in the areas of training on improved groundnut seed production. The training areas covered include both pre-production, production, harvest, and postharvest as well as business management skills. Basically, the IP members were trained on best practices for the production of improved seeds with particular reference to planting method (to maximize plant population), planting depth (for assured germinability), fertilizer requirements (for enhanced nutrition), and pest control strategies (for efficient health and wellbeing of plants) among others. IP members that received such trainings recorded higher yields than non-members in the same communities. Such trained farmers are most likely to practice the skills acquired compared to those who have not and in areas with limited access to good development intervention (APS 2014) (Fig. 6.1).

\subsubsection{Access to Improved Seeds and Their Types}

It was confirmed that, prior to the TL III project, groundnut producers mostly used local seeds because they have no access to seeds of improved varieties. Most of the local groundnut planting materials available to farmers for planting in the study area have low genetic potentials for pod yields, resistance to major pests and diseases as well as poor tolerance to drought. These constraints and many others result in low productivity of groundnut in Nigeria. The TL III intervention has increased farmers' access to improved groundnut seeds with spill-over effects to even beyond the IP member communities. The overall results showed that $88.7 \%$ of the beneficiaries now have access to quality improved seeds due to the TL III intervention compared to the previous access level of $26.3 \%$ before project. Majority (86.9\%) of the beneficiaries have adopted Samnut 24, one of the improved early varieties for production (Fig. 6.2).

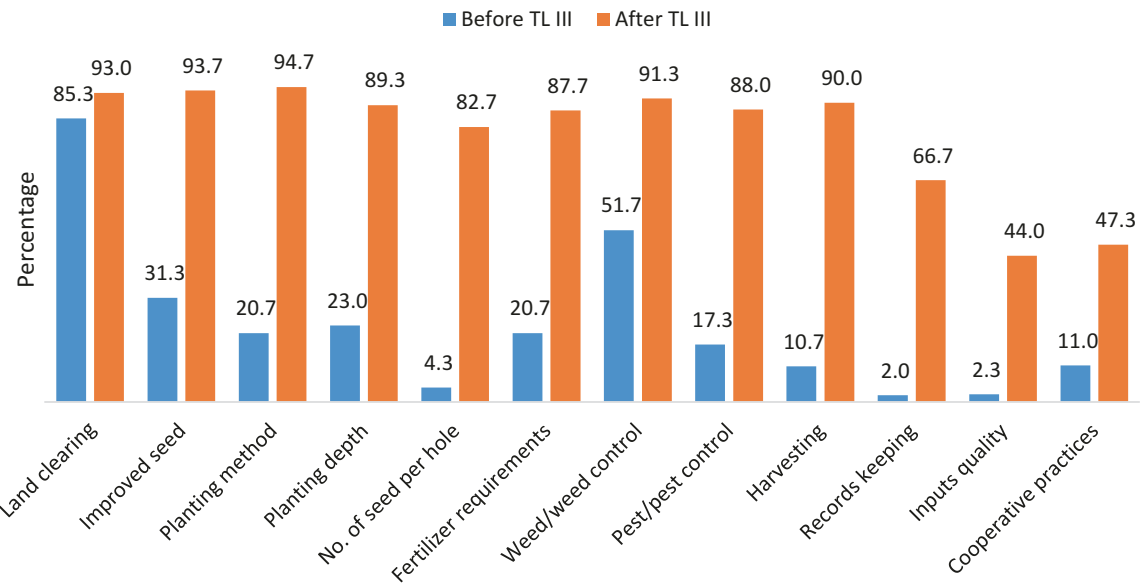

Fig. 6.1 Training on improved groundnut seed production 


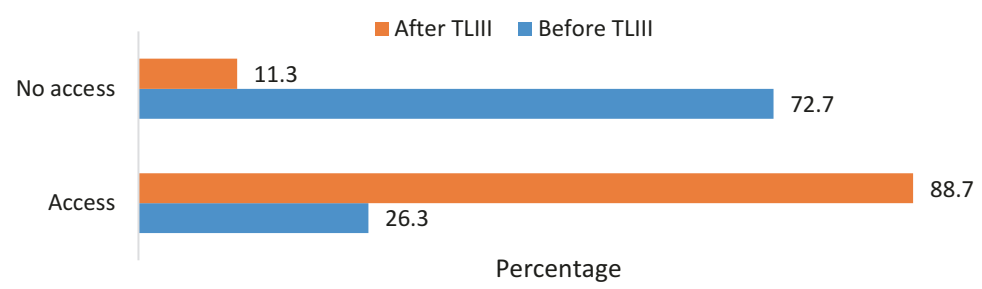

Fig. 6.2 Access to improved seeds

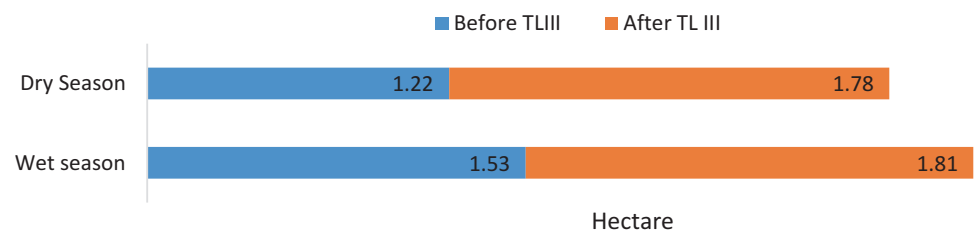

Fig. 6.3 Average farm size assessment

\subsection{Average Farm Size and Yield Assessment among Members}

Farm size and average yield are two primary parameters that determine farm productivity. This assessment indicated increase in farm size devoted for groundnut production during both wet and dry seasons. The average farm size for the dry season production was 1.22 ha and 1.78 ha before and after the project intervention, respectively. For the wet season, the average farm size increased from 1.53 to 1.81 ha. This impliedly showed expansion in farm area devoted for groundnut production among the IP members both wet and dry season productions, with greater increase in dry season than wet season (Fig. 6.3).

Similarly, the documentation exercise further computed the statistics of average pod yield ( $\mathrm{kg} / \mathrm{ha}$ ) obtained from the groundnut production activities. Findings indicated increased average yield for both wet and dry seasons. The average yield increased from 939 to $1217 \mathrm{~kg} / \mathrm{ha}$, recording about $29.6 \%$ increase for the wet season production. Similarly, the study revealed that the average yield for the dry season production increased almost ninefolds from 155 to $1352 \mathrm{~kg} / \mathrm{ha}$ per hectare (Fig. 6.4).

\subsection{Income Assessment of Groundnut Seed Producers}

The statistics for the groundnut farmers income assessment revealed positive improvement for both wet and dry season productions. The results indicated that the IP members accrued additional income ranging from $\$ 214$ to $\$ 453$ for wet season. The same increase in beneficiaries' income was reported for dry season groundnut 


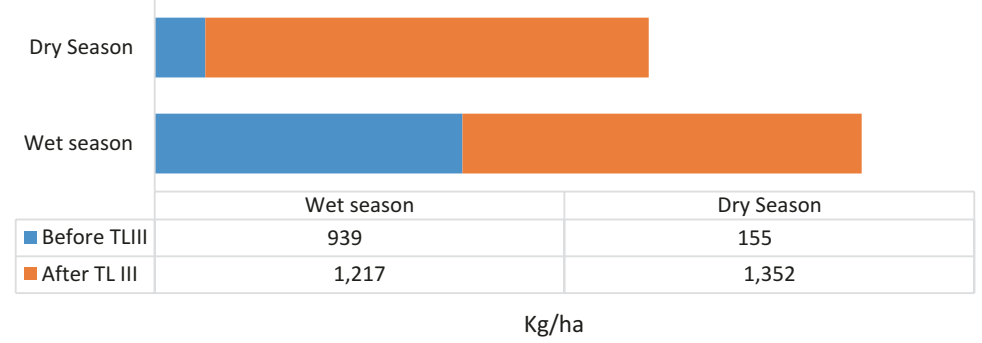

Fig. 6.4 Average yield assessment

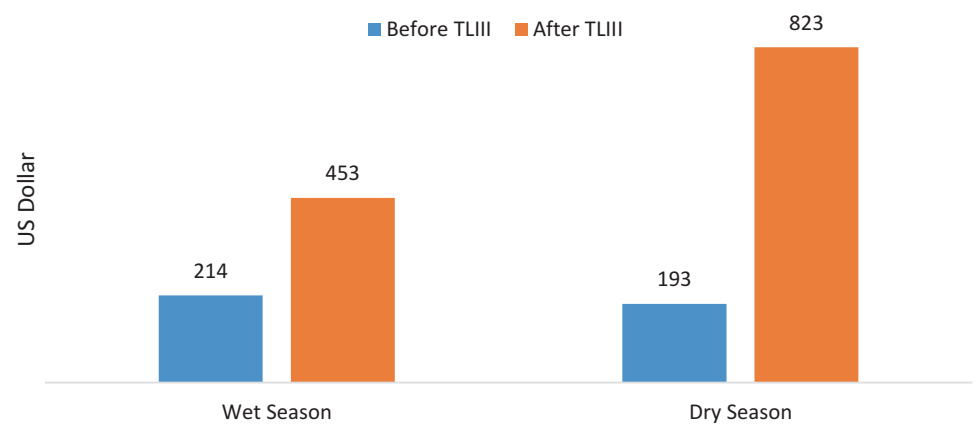

Fig. 6.5 Income assessment of groundnut seed producers

seed production from $\$ 193$ to $\$ 823$, after the TL III intervention. This implies positive contribution of the innovation platforms activities among the IP members. Diversification of income sources is a vital instrument for the development of farming activities, household living standard, and overall rural economic activities (Fadipe et al. 2014). It was observed that all income stream increased after the presence of the IP. The additional income obtained after TL III project can be used to improve other investment activities such as livestock production and off-farm enterprises among others (Fig. 6.5).

\subsection{Access to Markets, Financial, and Other Services}

Access to market among smallholder farmers in developing countries has been a serious challenge hindering increased agricultural activities in rural areas. The results from this study indicated increased access to market after TL III intervention as reported by $91.8 \%$ beneficiaries. Farmers were trained to produce quality outputs using quality inputs and other GAPs, which attracts market demand. Findings from the FGDs indicated that presence of off-takers, local processors, demand from other communities, and seed recovery by TL III are important in improving access to market. 


\subsection{Improvement in Market Price}

The prices at which farmers dispose agricultural commodities determine to some extent the level of profit to be generated per unit time. The higher the price of farm output, the higher will be the revenue obtained by smallholder farming households (Olukosi et al. 2008). The IP member responses revealed information about farmers' opinion on market price improvement of groundnut seeds before and after the TL III intervention. These findings revealed appreciable increase in the market prices of groundnut seeds as reported by $90.8 \%$ of the beneficiaries after executing the TL III activities in the project areas. Poor prices were reported before the TL III intervention as claimed by $71.2 \%$ of the IP members. Findings further revealed an average increased market price of $21.5 \%$ and $18 \%$ for dry and wet season groundnut as reported during the Focus Group Discussions, respectively. These increased prices of groundnut were reported as the major element of investment attraction in both wet and dry seasons.

\subsection{Access to Credit among IP Members}

Access to credit among smallholder farmers has been considered as major constraints affecting agricultural and other investment opportunities in developing countries. Within the IPs, it was reported that $40.7 \%$ of the beneficiaries had access to credit following the TL III intervention. Even though some improvements were recorded for access to credit from $1.7 \%$ before the TL III project, the current scenario is not enough for the farmers as reported during the FGDs. Similar findings on access to credit were reported by Mamman et al. (2016) who worked on socio-economic factors and income diversification affecting food security status of farming households in Jigawa state, Nigeria. The increasing access to credit can be attributed to the training and farmer sensitization to seek for more income to expand their agricultural production activities. The program of Anchor Borrower Scheme of the Federal Government of Nigeria is believed to have contributed to the increased access to credit.

\subsection{Cooperative Membership among Beneficiaries}

The study further provides information on cooperative membership among project beneficiaries. From the group statistics, majority (89.3\%) of the members belong to one cooperative group or another. There was increased participation in farmer organizations, as proved by members of the Ningi Groundnut Alkhairi Farmers' Association and Bela Groundnut Cooperative Farmers. Farmer cooperative organizations might be crop specific in rare cases and in most cases, they tend to be multipurpose, comprising many crop ventures. In any case, farmer associations are expected to render some essential benefits such as collective purchase of inputs, output marketing, social interaction, and learning of technology dissemination among its members (Ahmed et al. 2013) (Fig. 6.6). 


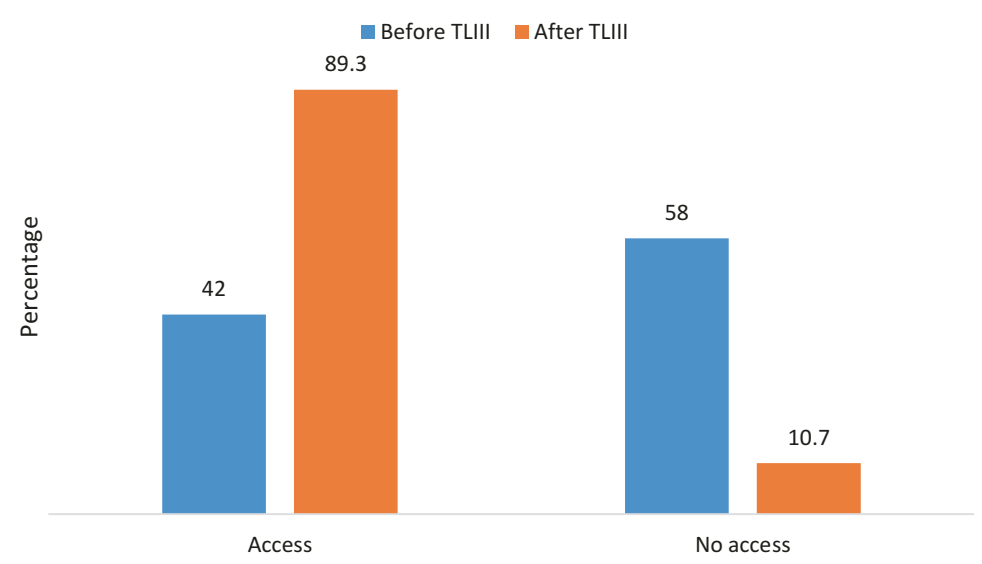

Fig. 6.6 Cooperative membership among beneficiaries

\subsection{Achievements in Areas of Social Assets}

Findings from this study revealed increasing participation in community social activities from $63.2 \%$ to $84.8 \%$ before and after the intervention, respectively. Participation in community social activities such as meetings and community development activities bring farmers together to interact, share knowledge and skills that might help them in improving production activities. The study further revealed that $17 \%$ of the IP members claimed improvement in their social assets, owing to their involvement in social participation.

The use of mobile phone in agricultural and other household economic activities has become a matter of importance and in most cases a serious concern to Government and other development agencies. Farmers are encouraged to accept the technology of modern communication systems. The response of the FGD indicated increased access to mobile phones from $61.4 \%$ to $82.7 \%$ for before and after the TL III project intervention. Farmers with improved access to mobile phone are likely better in receiving and sharing information on new technologies, input and output market prices, availability of improved seeds, and other GAPs techniques among others.

\subsection{Assessment of Innovation Platform Achievements}

\subsubsection{Members Perception on IP Performance}

The IPs have provided ground for supplying quality improved groundnut seeds, fertilizers, trainings, and access to market members and others in their communities. The study revealed that $89 \%$ of the beneficiaries assessed the IP performance as good while $11 \%$ reported moderated performance for the IPs. 


\subsubsection{Technology Adoption of Groundnut Seed Production under TL III Project}

The intervention provided to the IP a package of inputs and training supports on GAPs. This study therefore assessed the adoption of various component technologies with reference to conventional adoption stages. The component technologies assessed include improved seeds supply, choice of appropriate sowing date, sowing method (spacing inclusive), sowing depth, number of seeds per hole, fertilizer application, weed control as well as harvest and postharvest operations. Findings across technology components showed that farmers put into consideration the adoption stages (i.e., awareness, interest, trial, evaluation, and adoption). The statistics of the various component technologies revealed high adoption score of 0.79 with a grand adoption score mean of 0.76 (Table 6.2).

\subsection{Overall Benefits of the Innovation Platforms/Seed Support System}

Youth engagement in groundnut seed production was the most interesting emerging issue in most of the rural communities as reported by the Ningi Groundnut Alkhairi Farmers' Association and Bela Groundnut Cooperative Farmers. Findings from FGDs revealed that many young adults who traveled to distant places in search of jobs, now stay in their respective communities and put efforts to produce and sale groundnut seeds. This implied that the intervention has practically reduced ruralurban migration, which affects rural labor force engagement especially for agriculture. The IP supported improved groundnut grain production $(73.3 \%)$ by supplying the bulk improved seeds requirement to members of their communities. The supply of improved groundnut seed has greatly helped farmers who were earlier using seeds of local varieties before the TL III intervention. Other benefits reported among project beneficiaries include emergence of dry season seed production, which hitherto is not practiced in these communities. Similarly, women engagement in postharvest operations for them to generate income, training on improved groundnut seed production practices, cooperative participation among the farmers and improved access to extension services are important key benefits derived from the TL III intervention in the study area (Table 6.3).

\subsubsection{Comparison of Some Selected Key Variables by Gender}

\subsubsection{Assessment of Average Farm Size (ha) by Gender}

The statistics for farm size indicated that male devoted more farm size compared to female for both wet and dry season groundnut seed production. This can be attributed to the nature of farm ownership, access and control of households and individual resources in developing countries. The statistics of average yield obtained also follow similar trend, where male farmers obtained higher yields compared to their female counterparts, showing clear evidence of increasing productivity for 


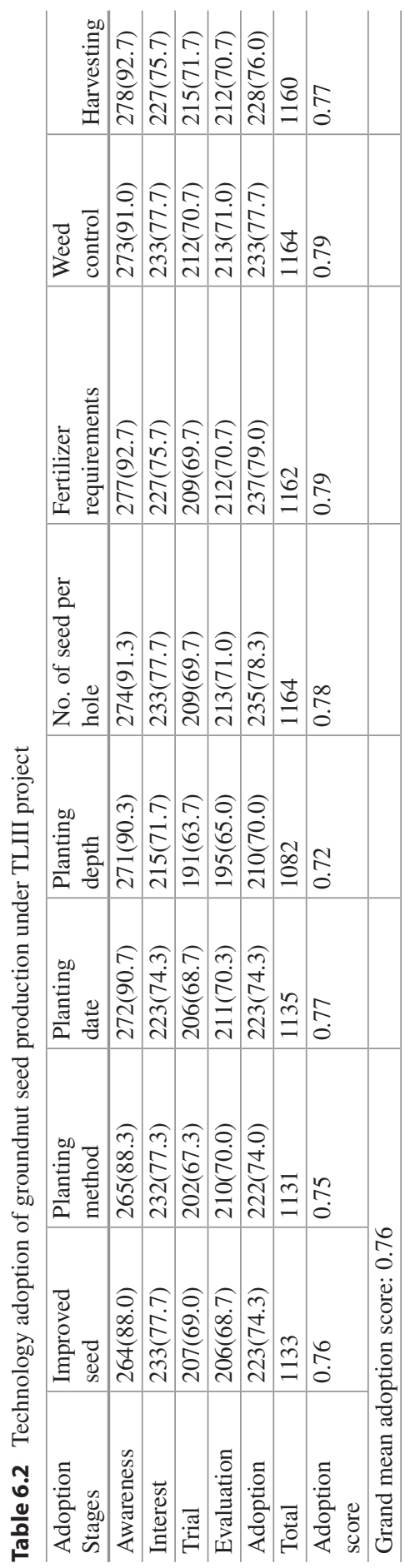


Table 6.3 Overall benefits of innovation platforms/seed support system

\begin{tabular}{l|l|l}
\hline Benefits & Percentage & Ranking \\
\hline Commercialization of groundnut seed production & 79 & 2nd \\
\hline Improved access to extension services & 65 & 7 th \\
\hline Support improved groundnut grain production & 78.3 & $3 \mathrm{rd}$ \\
\hline $\begin{array}{l}\text { Access to improved groundnut seed at } \\
\text { community }\end{array}$ & 73.3 & 4 th \\
\hline Acceptance of improved production technologies & 69.3 & 5 th \\
\hline Women engagement in postharvest operations & 59.3 & 6 th \\
\hline $\begin{array}{l}\text { Emergence of dry season groundnut seed } \\
\text { production }\end{array}$ & 52.7 & 9 th \\
\hline $\begin{array}{l}\text { Emergence of dry season grain production } \\
\begin{array}{l}\text { Knowledge/understanding on cooperative } \\
\text { participation }\end{array}\end{array}$ & 50.3 & 10 th \\
\hline $\begin{array}{l}\text { Youth engagement in groundnut production (dry } \\
\text { and wet) }\end{array}$ & 83 & 8 th \\
\hline
\end{tabular}

Table 6.4 Average farm size (ha) by gender

\begin{tabular}{l|l|l|l|l}
\hline \multirow{2}{*}{ Seasons/gender } & \multicolumn{3}{|l|}{ Before TLIII } & After TLIII \\
\cline { 2 - 5 } & Female & Male & Female & Male \\
\hline Wet season & 1.06 & 2.02 & 1.1 & 2.08 \\
\hline Dry season & 1.29 & 1.5 & 1.03 & 1.78 \\
\hline
\end{tabular}

both land and groundnut yield among the IP members. There was increasing participation of women in groundnut production as shown by the member composition of the farmer associations (Table 6.4) (Figs. 6.7 and 6.8).

\subsection{Constraints to Groundnut Seed Production}

The IPs ranked inadequate capital and credit facilities as the major constraints to groundnut seed production. This implied that, resource poor farmers could not purchase quality production inputs, pay for labor and efficient postharvest operations. Similar discoveries were made during the FGDs where farmers identified availability of capital, credit facilities, and transport as most important challenges to groundnut production in general. Other constraints include inadequate farm tools and equipment, pests and diseases problems as well as means to reduce drudgery, especially for women (Table 6.5).

\subsection{Reflections, Focus, and Lesson Learnt}

The IP system is believed to be ideal process to promote technologies to intensify agricultural production in local communities. The TL III as a development intervention has focused on enhancing smallholder farmers' access to improved seeds of 
Assessment of Average Yield (kg/ha) by Gender

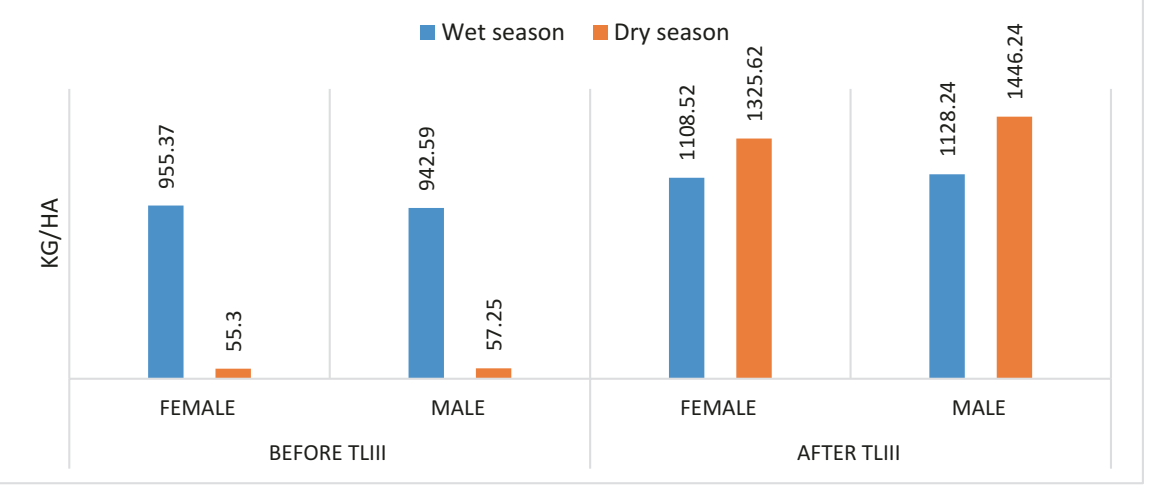

Fig. 6.7 Average yield ( $\mathrm{kg} / \mathrm{ha})$ by gender

Access to Seed, Market and Group membership by Gender

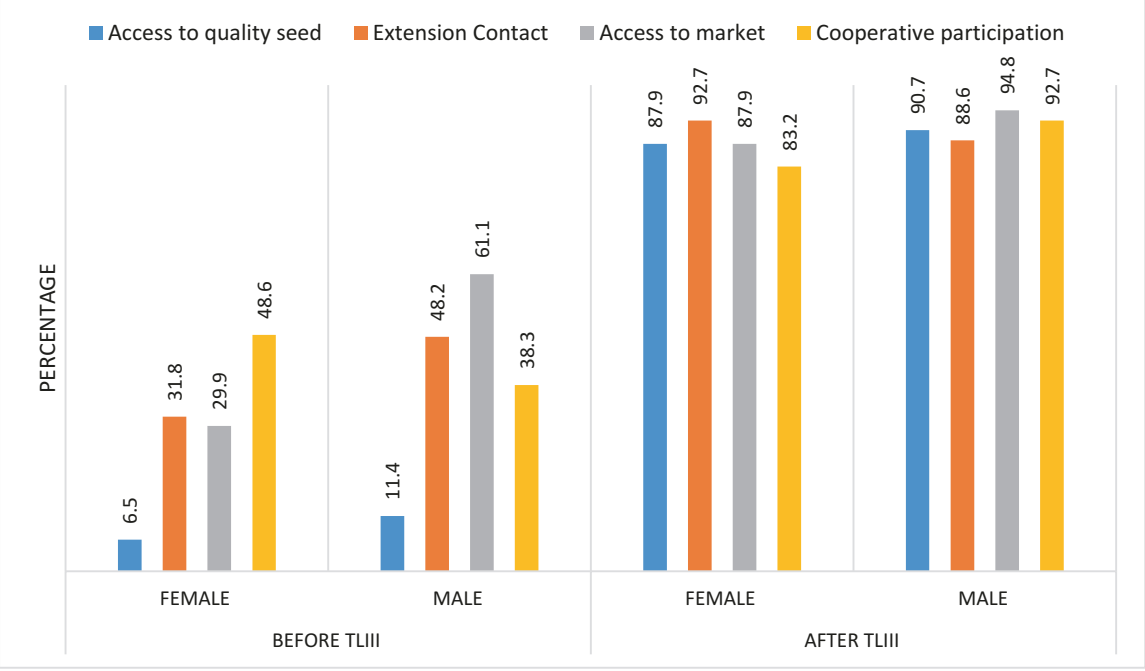

Fig. 6.8 Comparison of selected variables by gender

groundnut varieties through formation of multi-stakeholder platforms. Implementation evidence has shown that selection of appropriate project location, reliable beneficiaries, training and re-training on GAPs, and effective supervision on production activities are the major pillars of success of the TL III intervention in Nigeria.

\subsection{Areas of Focus in the Future}

Based on the reflections stated above, the following areas of focus are recommended for future interventions: 
Table 6.5 Challenges affecting groundnut production

\begin{tabular}{l|l|l}
\hline Constraints & Percentage & Ranking \\
\hline $\begin{array}{l}\text { Inadequate farm tools and } \\
\text { equipment }\end{array}$ & 81 & $3 \mathrm{rd}$ \\
\hline Inadequate capital & 85.7 & 1st \\
\hline Shortage of credit facilities & 82.3 & 2nd \\
\hline Cultural beliefs & 29.7 & 10th \\
\hline Pest and diseases & 68.3 & 4th \\
\hline Problem of ready market & 43.0 & 7th \\
\hline High cost of transportation & 49.3 & 5th \\
\hline Weak extension services & 37.3 & 9th \\
\hline Low selling price of groundnut & 43.3 & 6th \\
\hline Unfavorable climatic conditions & 24.7 & 11th \\
\hline Inadequate improved seed & 41.7 & 8th \\
\hline & &
\end{tabular}

- The need for replicating the intervention in other focal areas especially those with potentials for dry season groundnut production.

- The need to strengthen capacity building on GAPs to EAs and farmer group leaders who could train their members to build on the successes so far achieved.

- The need to create more awareness on the potentials of the Samnut varieties particularly for dry season production as a panacea to reducing unemployment in rural areas and rural-urban migration of youth and able-bodied persons.

- There is need to develop the capacity of the SHFs in business plan and management to enable them to decide on when, where and which groundnut variety to produce based on market demand.

- Attention should be given on gender balance in the subsequent and similar interventions to increase the proportion of participation of women in such development activities.

- There is need to evaluate the likely spill-over effects of the IP system and diffusion of the improved groundnut varieties to non-project LGAs and other neighboring states.

\subsection{Lessons Learnt}

This assessment has documented some lessons worthy of learning from the beneficiaries of the TL III intervention. These include:

- Timely provision of inputs, delivering appropriate pre-season training and follow-up supervisions by EAs are key to the success of innovation platforms.

- Women and youth have keen interest and are willing to engage in dry season groundnut production in areas with available sources of irrigation. This will reduce unemployment and involvement in social crimes among youth.

- Introduction of modern technologies requires multi-stakeholder approach and involvement of SHFs in cooperative groups or associations to share knowledge 
and skills. This will help in ensuring sustainability of the innovations for enhanced productivity.

- IPs have high potentials for spill-over effects as farmers in non-project communities are eager to access improved seeds and other GAPs from the beneficiaries.

- Market information is vital and strong for both input and output markets. This will enable smallholder farmers generate premium from sales of improved seeds.

- Availability of the IPs has attracted investors to express interest to engage SHFs into contract cultivation of improved groundnut varieties thereby confirming assured market.

Acknowledgements The authors like to acknowledge all the stakeholders (Farmers, EAs, State ADPs, Seed Companies, Input Dealers, Marketers, and Community Leaders) involved in the conduct of the TL III project in Nigeria.

\section{References}

Agricultural Performance Survey - APS (2014) Agricultural performance survey in Nigeria: an annual report of wet season agricultural performance survey conducted by National Agricultural Extension Liaison Services. Ahmadu Bello University, Zaria

Ahmed AS, Suleiman A, Aminu A (2013) Social and economic analysis of small-scale maize production in Kura local government area of Kano State, Nigeria. Int J Agric Sci Res Technol Ext Educ Syst 3(1):37-43

Fadipe AE, Adenuga AH, Lawal A (2014) Analysis of income determinants among rural households in Kwara state, Nigeria. Trakia J Sci 4(2):400-404. Trakia University, Available online http://www.uni-sz.bg

Mamman BY, Wudil AH, Halliru M (2016) Socio-economic factors and income diversification affecting food security status of farming households in Jigawa state, Nigeria. In: Proceedings of the 1st international conference on Drylands agriculture, pp 109-118

Olukosi JO, Isitor SU, Ode MO (2008) Introduction to agricultural marketing; principles and application, 3rd edn. G. U. Publisher, Abuja, pp 47-57

Open Access This chapter is licensed under the terms of the Creative Commons Attribution 4.0 International License (http://creativecommons.org/licenses/by/4.0/), which permits use, sharing, adaptation, distribution and reproduction in any medium or format, as long as you give appropriate credit to the original author(s) and the source, provide a link to the Creative Commons license and indicate if changes were made.

The images or other third party material in this chapter are included in the chapter's Creative Commons license, unless indicated otherwise in a credit line to the material. If material is not included in the chapter's Creative Commons license and your intended use is not permitted by statutory regulation or exceeds the permitted use, you will need to obtain permission directly from the copyright holder.

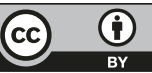

